\title{
Announcing a New A.C.R.L. Service
}

Mr. Hamlin is executive secretary of the Association of College and Reference Libraries.

College and Research Libraries will $\checkmark$ be sent to all members of A.C.R.L. paying A.L.A. dues of $\$ 5.00$ or more starting with the July 1952 issue. Board action taken at the Midwinter Meeting approved this decisive step (subject to certain findings just now completed) and directed the executive secretary to work out the details. The A.C.R.L. Quarterly Newsletter will be given up at that time.

Members are well aware of the pressure exerted during past years in behalf of a free journal. This was based on substitution of College and Research Libraries for the A.L.A. Bulletin. Such substitution seemed impractical, and last year I prepared estimates on costs independent of any subvention by A.L.A. These estimates were encouraging and were approved by the Board of Directors last July, subject to further study by a committee chairmanned by Stanley E. Gwynn.* This committee reported favorably, and the board took final action as noted above.

A great deal of detailed work is required to adjust to the new basis. Subscriptions should be allowed to run out in order to avoid an expensive refunding operation. Advertising rates will be raised, and new advertisers sought. Mailing and record routines all must be changed.

College and Research Libraries subscriptions have increased rapidly in the past

* Other Members: Jens Nyholm, Maurice F. Tauber, Arthur T. Hamlin. two years, and the journal is now just about self-supporting. There will be no more special issues, but present size and quality will not be reduced.

The present principal costs of manufacture will cost about $\$ 1800$ per year more for 3500 additional copies. Postage will increase $\$ 400$; other costs remain stationary or decrease.

Preparation of manuscript including proofreading, make-up and much business detail remains at its present figure of $\$ 850$ annually. For "office services" (billing, recording subscriptions and some minor details) A.L.A. charges $\$ 1800$. This will be largely eliminated. We are fortunate in having no editorial costs except a minor one for secretarial help. This expensive function is performed freely, and most competently, by our Board of Editors.

College and Research Libraries cost nearly $\$ 10,000$ to produce in 1949-50. With the elimination of special issues and with the savings mentioned above this same sum should come close to providing copies for all members paying $\$ 5.00$ or more A.L.A. dues.

A summary of the income estimates of Mr. Gwynn's committee is as follows: (I) Advertising rêvenue was $\$ 1600$ last year and is increasing; an annual revenue of $\$ 3900$ can be reached by 1954 , provided a lot of hard work is done. This estimate has been approved by an advertising expert. (2) Nonmember subscriptions now bring about $\$ 2800$ and will not be affected. (3) Sale of extra copies may drop from the present level of $\$ 650$ to $\$ 400$. (4) 500 new members paying $\$ 5.00$ or more may be at- 
tracted to join A.C.R.L. to raise the present number from 4623 to about 5 I 50. While only 60 cents comes in from $\$ 3.00$ A.L.A.A.C.R.L. memberships, 60 per cent of all other memberships (up to $\$ 6.00$ ) comes to A.C.R.L. It is estimated that $\$$ I 500 of this expected new revenue might be assigned to College and Research Libraries. (5) The elimination of the Quarterly Newsletter means an annual saving of $\$ 800$. A gap of only about $\$ 600$ is left between anticipated costs and estimated income.

The Board of Directors is well aware that we live in an uncertain age and that conditions a year and a half hence may be very different. Within our own organization such matters as changes of A.L.A. dues may decrease, or increase, A.C.R.L. income. The A.L.A. dues report rejected at midwinter would certainly have resulted in a decline for this division. The question of paper supply cannot be guaranteed, but a probable second source of supply has been found should rationing curtail the use of A.L.A. stocks. I believe the board felt, as
I do, that chances for success were sufficiently good, and the objective so important, that we should move forward unless harsh realities absolutely forced retrenchment.

The success of the whole venture depends on no manipulation of figures in this office and somewhat less on what Mr. Stalin may be planning than on the interest and activity of every member. We must have ads. We count on every reader with purchasing power to use influence to help us. We need the assistance of each and every one to recruit new members. Here is a major step taken in behalf of all of us, to help us and to help our profession. Here is a cut in the cost of living, if you will, dependent on joint enterprise and cooperation. The project can fail if it does not have active, positive support. We cannot wait until July I 952 to gather strength. We must begin now.

There are many details to be worked out about closing out subscriptions, increasing advertising rates and similar matters. These will be announced in future issues.

\section{S.L.A. Represented on Joint Committee on Indexing and Abstracting}

Mrs. Irene M. Strieby has called to my attention an error in my article on "Indexing and Abstracting: Recent Past Lines of Future Development" in College and Research Libraries, for July, 1950, p.199. I there stated that the Special Libraries Association never appointed a member of the Joint Committee on Indexing and Abstracting in Major Fields of Research. It appears that Maria C. Brace was appointed to the committee as the S.L.A. representative in I939 (S.L.A. Proceedings, May 23-27, 1939, p.13. Miss Brace's report appeared in Special Libraries $31: 286,1940)$. She was succeeded by Margaret Miller who served through 1943. It was only for the last two years of the committee's life (I944 and I945) that the A.L.A. Handbook records that "no appointment" had been made to represent S.L.A. in the committee. -Verner W. Clapp.

\section{Copies of Ten-Year Index Available}

Copies of the Ten-Year Index to College and Research Libraries, Volumes I-X, 1939-49, which was published as Part II of the July 1950 issue of College and Research Libraries, are still available at $\$ 1.25$. These may be ordered from the American Library Association, 50 E. Huron St., Chicago I I. 